\title{
ATTEMPT OF CLASSIFICATION OF THE PUBLICISATION OF CIVIL MATTERS BASED ON RECENT EXAMPLES FROM POLAND'1
}

\author{
Anna Piszcz \\ University of Białystok, Faculty of Law
}

\begin{abstract}
The purpose of this paper is to assess the phenomenon of the publicisation of civil matters in Poland against the background of the current legislation and the practice observed by the Author, as well as, based on the conducted analysis, to offer a classification of the publicisation. The analysis is based on the following main elements. First, it attempts to provide an overview of what may be considered the most significant features for each of the examples of this phenomenon. Third, it looks at what the publicisation is driven by and whether there is a fiscal function provided for in its case. Fourth, it analyses available data to verify whether there are growing numbers of decisions taken in each category of the publicisation outlined in the paper.
\end{abstract}

Keywords: civil matters, private law, public law, privatisation, publicisation, de iure publicisation, de facto publicisation, de-privatisation

\section{INTRODUCTION}

The main focus of this paper is on a phenomenon that appeared in Poland with regard to some civil matters and could be called the publicisation of civil (private) matters. The publicisation of civil matters does not seem a unique phenomenon that does not exist in the other EU countries; to the contrary, from time to time various national legislatures decide to "publicise" a given category of civil matters for various reasons. However, in Poland it happened to a few categories of civil matters within a quite short period of time and, as such, made me reflect on whether perhaps it is already a tendency (trend) regarding the relationship between private and public enforcement of law. The division of law enforcement into private enforcement and public enforcement should be a point of departure for further considerations. This division follows the Ulpian's (who was a jurist in ancient Rome) division of law into two fundamental branches: private law (relating to the interest of individuals) and public law. ${ }^{2}$ The border between them does not seem as clear as it used to be, since contemporary commentators identify phenomena such as privatisation of public law and publicisation of private law. ${ }^{3}$ Private enforcement of law is carried out under private (civil) law and one

1 This paper is to large extent a re-print of the Author's paper on "Publicisation as the Transfer of Competences from Civil Justice to Public Administration: An Attempt of Classification and Recent Examples from Poland" (publ. University of Szeged). The paper was presented, first, at the Pázmány Péter Catholic University on 01. 06. 2018 and, second, at the University of Szeged on 25. 09. 2018.

2 For example, see: WATSON, A. The State, Law, and Religion. Pagan Rome. Athens and London: University of Georgia Press, 1992, pp. $21-29$.

3 Among others, MICHELON, C. The Public, the Private, and the Law. In MAC AMHLAIGH, C., MiCHELON, C. \& WALKER, N. (eds). After Public Law. Oxford: Oxford University Press, 2013, pp. 83 - 100; HELIOS, J. Publicyzacja prawa prywatnego - prywatyzacja prawa publicznego w kontekście rozważań nad prawem europejskim [Publicisation of private law - privatisation of public law in the context of considerations on European law]. In Acta Universitatis Wratislaviensis Przegląd Prawa i Administracji. Vol. 92 (2013), pp. 11 - 36. 
can realise the crucial role of civil courts therein. Public enforcement of law is carried out by other authorities. For a given category of legal provisions it may be decided by national laws that they are enforced both privately and publicly (dual system) or only in one way (non-dual system). Dual systems seem particularly challenging. On one hand, they may bring more efficiency into the law enforcement but, on the other hand, there are particular needs inherent in them, such as the need for effective interaction of private enforcement and public enforcement as well as for their coordination in a coherent manner. ${ }^{4}$

For the purposes of this paper the publicisation shall be understood as the introduction of public enforcement for matters that so far have been enforced (or have been able to be enforced) privately. At the end of this paper a classification of the publicisation will be offered.

Each of the three main parts of the paper shall present one example of each category of the publicisation. They are also going to elaborate, in particular, on what their introduction is driven by, whether there is a fiscal function provided for in their case and whether there are growing numbers of decisions taken in each category outlined in the paper. The point of the analysis is both normative and descriptive. Not coincidentally, each example is related to the Polish competition authority, that is the President of the Office of Competition and Consumer Protection. ${ }^{5}$ It was the development of the UOKiK President's competences that inspired the contents and title for this paper.

\section{EXAMPLE REGARDING THE PROHIBITION OF UNFAIR TRADING BUSINESS-TO-BUSINESS PRACTICES}

A key example of the publicisation of civil matters in Poland in recent years at which one may look for the purposes of this analysis is related to the prohibition of the unfair abuse of bargaining power (unfair trading practices, UTPs) between entrepreneurs in business-to-business food supply chains. Previously this prohibition could have been enforced only before civil courts (but in fact it hardly was, so this paper does not discuss the issue of the practical application of its private enforcement) and from $12^{\text {th }}$ July 2017 it may be combatted - in addition or alternatively - in administrative proceedings conducted on the basis of a new statute, i.e. 2016 Act on Combating the Unfair Use of Superior Bargaining Power in the Trade in Agricultural and Food Products. ${ }^{6}$ Pretty coincidentally, the adoption of the Polish statute was followed by the EU development in the field, i.e. the draft Directive of the European Parliament and of the Council on unfair trading practices in business-tobusiness relationships in the food supply chain ${ }^{7}$ that was published on $12^{\text {th }}$ April $2018 .^{8}$

4 For example, see: Directive 2014/104/EU of the European Parliament and of the Council of 26. 11. 2014 on certain rules governing actions for damages under national law for infringements of the competition law provisions of the Member States and of the European Union, OJ L 349, 05. 12. 2014, pp. 1 - 19.

5 In Polish: Prezes Urzędu Ochrony Konkurencji i Konsumentów; hereinafter, UOKiK President.

6 Act of 15. 12. 2016 on Counteracting the Unfair Use of Superior Bargaining Power in the Trade in Agricultural and Food Products (Journal of Laws of the Republic of Poland 2017, item 67).

$7 \operatorname{COM}(2018) 173$ final, 2018/0082 (COD).

8 In the "Report from the Commission to the European Parliament and the Council on unfair business-to-business trading practices in the food supply chain" of 29. 01. 2016, the Commission concluded that at this stage there was no need for EU legislative measures in the field of unfair trading practices (as if there was a possibility the markets would "sort itself out" naturally through the normal market forces) and, consequently, regulatory initiatives in the discussed field were left to Member States. However, within one year from the publication of the Commission's report, the European 
The public enforcement of the UTPs' prohibition is currently tested by the Polish enforcement authority. It is now nearly October 2018, and not much has been heard: the latest update is that only one "pilot" case has been concluded with a decision that was adopted on $5^{\text {th }}$ March $2018^{9}$ and over twenty new proceedings are pending. ${ }^{10}$ In order to probe on reasons of the adoption of the Act, it is necessary to analyse the explanatory notes ${ }^{11}$ accompanying the draft Act and performing a largely justificatory function. Judging from this document, inefficiency of private enforcement was one of the main reasons for the publicisation. Provisions of the 1993 Act on Combating Unfair Competition, ${ }^{12}$ to the extent that they cover the unfair use of superior bargaining power, have been, de facto, considered difficult to enforce and ultimately ineffective. Weaker parties to commercial transactions have often been afraid of retaliation and/or compromising an existing commercial relationship with the stronger party (the so-called "fear factor"). ${ }^{13}$ Owing to this, they have not been willing to seek redress before a court of civil law even till the end of the relationship. This has not translated into a lack of such civil cases, since from time to time, after the termination of the relationship, the weaker party has indeed pursued a so-called "divorce case" and sought redress (even though in practice civil proceedings might have been long-lasting and expensive). ${ }^{14}$

Under the 2016 Act administrative proceedings are initiated by the enforcement authority ex officio. ${ }^{15}$ In fact, it means that, due to limited resources of the enforcement authority, less troublesome practices have to be sifted out and the other practices have to be selected for more detailed investigation from the entire cross-section of practices. Injured parties are not parties to the administrative proceedings. What the authority can also do in investigated cases is the imposition of fines of up to $3 \%$ of annual turnover of the infringer. ${ }^{16}$ The provisions providing for the high statutory maximum of fines offer an opportunity to reflect upon whether or not under the new status quo a fiscal function is performed by public law provisions. There are not sufficient sources, however, to effectively examine a phenomenon from this perspective, since - as it has been mentioned - there has been only one decision of the enforcement authority so far and it has not imposed any fine on the alleged infringer (commitment decision). It is difficult (if not impossible) to figure this challenging conundrum out due to a general lack of experience of the enforcement authority.

The example described above may be classified as the publicisation largo sensu. In brief, publicisation largo sensu may be understood as adding legal bases for public enforcement of given provi-

Parliament (resolution of 07. 06. 2016 on unfair trading practices in the food supply chain, No. P8_TA(2016)0250), the European Economic and Social Committee (opinion of 30. 09. 2016 on report from the Commission to the European Parliament and the Council on unfair business-to-business trading practices in the food supply chain, No. NAT/680) and the Council all called for actions to be taken at the EU level (conclusions of 12.12.2016 on strengthening the position of farmers in the food supply chain and tackling unfair trading practices, No. 15508/16).

9 Decision of 05. 03. 2018, No. RBG-3/2018. In Polish available at: <https://decyzje.uokik.gov.pl/bp/dec_prez.nsf> (all Internet references in this paper were accessed: 27. 09. 2018).

10 In Polish available at: <https://uokik.gov.pl/aktualnosci.php?news_id=14634 \& news_page=2>.

11 In Polish available at: <http://www.sejm.gov.pl/Sejm8.nsf/druk.xsp?nr=790>.

12 Act of 16. 04. 1993 on Combating Unfair Competition (consolidated text Journal of Laws of the Republic of Poland 2018, item 419).

13 Explanatory Memorandum to the draft Directive of the European Parliament and of the Council on unfair trading practices in business-to-business relationships in the food supply chain (note 7), p. 2, 5-6, 10.

14 PISZCZ, A. The EU 2018 Draft Directive on UTPs in B2b Food Supply Chains and the Polish 2016 Act on Combating the Unfair Use of Superior Bargaining Power in the Trade in Agricultural and Food Products. In Yearbook of Antitrust and Regulatory Studies. Vol. 11(17) (2018).

15 Article 10 of the 2016 Act.

16 Article 33 of the 2016 Act. 
sions by the legislature to already existing legal bases for their private enforcement. This puts the dual model of enforcement into force. The assumption which has to be made here is that there have been no legal bases for public enforcement of these provisions directly prior to the introduction of these new legal bases, so such publicisation equals to regulation or re-regulation (after a period of the lack of regulation) of a given category of matters.

\section{EXAMPLE REGARDING THE ABSTRACT CONTROL OF STANDARD FORMS OF AGREEMENTS CONCLUDED WITH CONSUMERS}

In this section, the abstract control of standard forms of agreements concluded with consumers that used to be a competence of a civil court, i.e. the Regional Court of Warsaw XVII Division called Court of Competition and Consumer Protection - will be reviewed concisely as an example of the publicisation. ${ }^{17}$ One of the assumptions which have to be made here is that there have been legal bases (in Civil Procedure Code ${ }^{18}$ ) for private enforcement of given provisions beforehand, regardless of the range and quality of their application. Then, in place of them the legal bases for public enforcement have been introduced. This new model shows features of the non-dual model.

The new provisions were added to 2007 Act on Competition and Consumer Protection on 17 April $2016^{19}$ and have not been further refined. With the new legislation, the administrative proceedings initiated ex officio by the UOKiK President have been introduced instead of private enforcement. ${ }^{20}$ The fact that the new legislation does not give the right to initiate abstract control proceedings (and to be the party to those proceedings) to any other entity constitutes a major change - raising concerns related to the right to a fair trial - in comparison to the previous court proceedings model, where a lawsuit brought by an authorized entity initiated the civil proceedings. $^{21}$

As for decisions adopted under the new provisions there must be emphasised that in the quite short period of their application there have not been plenty of decisions issued. The number of them is only nine for around 2.5 years. ${ }^{22}$ And, characteristically, the first decision was adopted by the authority on 5 June 2017, that is more than one year after the entry of the new provisions into force.

The main reason behind the new legislation was the flood of actions that the only competent Polish court suffered from. Those civil cases were free of court registration fees. On the other hand, a winning party represented by a professional lawyer (an advocate or an attorney-at-law) could have

17 The introduction into domestic legal systems of rules that enable control of terms used in contracts concluded with consumers by sellers or suppliers is required by Council Directive 93/13/EEC of 05. 04. 1993 on unfair terms in consumer contracts, OJ L 95, 21. 04. 1993, pp. 29 - 34.

18 Act of 17. 11. 1964 - the Civil Procedure Code (consolidated text: Journal of Laws of the Republic of Poland 2018, item 1360 as amended).

19 Act of 16. 02. 2007 on Competition and Consumer Protection (consolidated text Journal of Laws of the Republic of Poland 2017, item 229 as amended).

20 Article $49 \mathrm{sec} 1$ of the 2007 Act.

21 See also KORYCIŃSKA-RZĄDCA, P. Review of the New Polish Model of Abstract Control of Standard Forms of Agreements Concluded with Consumers. In Yearbook of Antitrust and Regulatory Studies. Vol. 9(14) (2016), p. 253.

22 In Polish available at: <https://decyzje.uokik.gov.pl/bp/dec_prez.nsf>. 
received the costs of legal aid resulting from the tariffs provided for by law ${ }^{23}$ and not from the actual expenditure. This resulted in cost pathologies. The consumer organisations being in fact "factories" of such actions appeared in Poland; they used to copy the same template of an action regarding the same clauses from the same standard form of agreements concluded with different, numerous consumers in order to win as much lawyers' fees "reimbursement" from the infringer as possible at a very low "price". The information announced by the Ministry of Justice every year ${ }^{24}$ (based on data available from the court) makes it clear that from 2008 to 2013 the number of filed actions was growing very fast; the information shows its increase in $2008-2010$ from 325 to as many as 3,909 actions and the further growth to 41,016 actions in 2013. It was reduced for the first time in 2014 to 3,109 actions, thanks to a reduction in lawyers' fees in those proceedings, which took place in $2013^{25}$ and, in figures released recently, the number of actions amounted to 1,859 in 2016 . One can realise, first, so much of civil justice for so little money (no court registration fee!) and, second, making money on the reimbursement of lawyers' fees at which actions from the "factories" were aimed. So, the main reason behind the change was inefficiency too, like in the first example shown in the part 2 of this paper. The details on how that inefficiency looked like were, however, different. The most basic difference was that in the first example private actions had been quite rare and here, to the contrary, the right to trial before the civil court had been significantly abused.

Under the new legislation, the enforcement authority has the possibility to impose fines of up to $10 \%$ of the infringer's annual turnover on the infringer. Again, a look at whether this provision performs or is to perform a fiscal function can be taken. Interestingly, fines for the usage of prohibited clauses in standard forms of agreements have been imposed on entrepreneurs in four out of nine cases. They amounted to around thousand Euro, ${ }^{26}$ over 40 thousand Euro ${ }^{27}$ and over 1,300 thousand Eur. ${ }^{28}$ It must be explained that their amounts were dependant on a given entrepreneur (its turnover) and the gravity of practices in question. The legal bases for public enforcement have been in force with regard to the discussed type of practices for only around 2.5 years now and, so far, the system has not shown any sign of considerable severity of fines confirming their fiscal function.

This example of the publicisation of civil matters shows their de-privatisation, i.e. moving them by the legislature from civil proceedings to administrative proceedings. This is the publicisation stricto sensu.

\section{EXAMPLE REGARDING THE PROHIBITION OF ANTI-CONSUMER PRACTICES}

The last example is related to the phenomenon that appeared in Poland in consumer matters. Anticonsumer practices may be combatted both before civil courts and in administrative proceedings

23 The Ordinance of the Minister of Justice of 22. 10. 2015 on legal advisors' fees (consolidated text Journal of Laws of the Republic of Poland 2018, item 265) and the Ordinance of the Minister of Justice of 22. 10. 2015 on advocates' fees (Journal of Laws of the Republic of Poland 2015, item 1800).

24 Available at <http://isws.ms.gov.pl/pl/baza-statystyczna/opracowania-jednoroczne/rok-2016/download,3369,4.html>, $<$ http://isws.ms.gov.pl/pl/baza-statystyczna/opracowania-jednoroczne/rok-2014/download,2834,10.html >, <http://isws. $\mathrm{ms.gov.pl/pl/baza-statystyczna/opracowania-wieloletnie/download,2577,5.html>.}$

25 KORYCIŃSKA-RZĄDCA, P. (note 21), p. 263.

26 Decision of 22. 12. 2017, No. RBG-8/2017 and decision of 22. 12. 2017, No. RBG-9/2017.

27 Decision of 28. 12. 2017, No. RŁO-9/2017.

28 Decision of 12. 12. 2017, No. RWR-10/2017. 
(in this last case - anti-consumer collective practices regulated by the 2007 Act on Competition and Consumer Protection). The existing dual system is a concoction of private enforcement and public enforcement. In fact, however, when those two elements provided for in the legal provisions come together, it does not result in an efficient system of enforcement. There are not many civil cases regarding unfair $\mathrm{B} 2 \mathrm{C}$ practices; empowered persons are usually passive even though it results in that consumers remain uncompensated (or at least undercompensated). However, during some administrative proceedings (initiated ex officio ${ }^{29}$ ) the UOKiK President as a competent enforcement authority tends to oblige an entrepreneur to offer to individual consumers the so-called public compensation (within a broader and quite imprecise competence to impose obligations on entrepreneurs ${ }^{30}$ ). By this, in fact the administrative authority is a "mixed bag" of regulatory competences and adjudicative function in its private (civil) sense.

The notion of the public compensation and the new practice of the Polish competition and consumer protection authority appeared in 2015. ${ }^{31}$ Again, one of the reasons for this new decisionmaking practice has been inefficiency of private enforcement that could be seen in particular in the passivity of consumers. Another prominent reason openly discussed in the UOKiK has been the repeated relaxation of imposed fines by the Court of Competition and Consumer Protection as a specialized court of the first instance dealing with appeals from the UOKiK President's decisions and the Court of Appeals of Warsaw as a court of the second instance. ${ }^{32}$ Whatever the reasons of those reductions were, they have been an important incentive for the UOKiK President, on the one hand, to modify the fining policy, and on the other hand, to look for other instruments aimed at the sustained elimination of anti-consumer practices. The public compensation has been employed by the UOKiK President as such an instrument used in commitment decisions and/or in infringement decisions without fines or combined with lower fines. If the public compensation implies a lower fine (or no fine at all), then it is unlikely to perform a fiscal function. However, it is believed by the UOKiK President that the public compensation, either alone or in combination with a fine, fulfils a repressive function (as it requires the infringer to bear financial burden of practices), but also makes consumers benefit directly from the UOKiK President's proceedings. ${ }^{33}$

From 2015 until the end of September 2018 there have been at least 38 decisions of the UOKiK President providing for public compensation (including 31 commitment decisions, three infringement decisions without fines and four decisions with fines of various amounts ${ }^{34}$ ). To consumers such decisions mean they will be compensated and will not need to go - for this purpose - to civil courts,

29 Article $49 \sec 1$ of the 2007 Act.

30 Article $26 \mathrm{sec} 2$ and Article $27 \mathrm{sec} 4$ of the 2007 Act. In the case of commitment decisions see Article 28 of the 2007 Act.

31 See UOKiK, Public compensation in UOKiK's decisions, available at <https://uokik.gov.pl/news.php?news_id=12159>.

32 In Polish available at <https://www.uokik.gov.pl/aktualnosci.php?news_id=12156>. On reductions see e.g. BERNATT, M. Czy Polska oferuje więcej niż wymaga Konwencja? O konwencyjnym wymogu pełnej jurysdykcji i polskim modelu sądowej kontroli kar nakładanych przez Prezesa UOKiK [Does Poland offer more than the Convention requires? On the conventional requirement of full jurisdiction and the Polish model of judicial control of fines imposed by the UOKiK President]. In JASIŃSKI, W. (ed). Między prawem administracyjnym a prawem karnym. Standardy rzetelności postępowania w sprawach ochrony konkurencji i konsumentów [Between administrative law and criminal law. Standards of fairness of proceedings in cases of competition and consumer protection]. Warszawa: Wolters Kluwer, 2016, pp. $131-153$.

See note 31

34 Decision of 30. 12. 2015, No. DDK-28/2015, T-Mobile, over 1 million Euro; decision of 30. 12. 2015, No. DDK-30/2015, Multimedia Polska, over 1.1 million Euro; decision of 29. 07. 2016, No. RBG-5/2016, UPC Polska, over 190 thousand Euro; decision of 30. 12. 2016, No. DDK-26/2016, Orange Polska, over 6.6 million Euro. Due to public compensation those fines were reduced by 25 to even 90 per cent. 
either individually or in group proceedings. ${ }^{35}$ In the UOKiK President's view, a decision providing for public compensation not only has an effect for the future (consumers will not be exposed to an anti-consumer practice and will no longer suffer harm), but also acts "retroactively", thereby leading to direct compensation of the consumers' harm suffered so far. ${ }^{36}$ The UOKiK Vice-President said to media that public compensation made consumers benefit directly from administrative decisions. ${ }^{37}$ There is something to it, though, as e.g. subscribers to T-Mobile network will readily agree, as one of the UOKiK President's decisions required T-Mobile to pay customers PLN 65 (EUR 14,5) for informing them unduly that it was raising monthly subscription charges for cellphones by PLN 5 (EUR 1,1). ${ }^{38}$ In the absence of this decision, if the service provider did not agree for consensual means of the dispute resolution (settlements), for many of those subscribers the pursuit of actions claiming from the service provider to pay PLN 65 would not have any chance to happen because of many various reasons including the small amount of claim, the time and knowledge needed to conduct the case on their own and costs that would need to be paid to a lawyer in case of professional representation. Thus, the public compensation may be viewed as the gateway to compensation in the case of small dispersed claims of consumers.

Polish commentators' concerns related to the public compensation are all about its nature. ${ }^{39}$ This remedy as a new additional element of administrative decisions is considered to be getting closer to fines, whereas civil (and not administrative) proceedings have always been the right means to obtain compensation by consumers. ${ }^{40}$ That is why in mid-2018 the Polish government criticised ${ }^{41}$ Article 6(1) of a draft directive of the European Parliament and of the Council on representative actions for the protection of the collective interests of consumers, and repealing Directive 2009/22/EC ${ }^{42}$ providing for a redress order issued also by administrative authorities. It is believed by the government that the proposed procedure cannot replace group proceedings. Furthermore, in their opinion draft provisions providing for the combination of injunctions and collective redress in respect of civil claims are doubtful, since such combination is unacceptable under the Polish legal system where civil claims can be resolved only by courts. The government did not manage to see that this system already operates quite efficiently in the case of decisions issued by the UOKiK President (the central governmental authority). Some UOKiK President's decisions providing for public compensation have been appealed to the Court of Competition and Consumer Protection. It remains to look

35 On Polish group proceedings see e.g. PISZCZ, A. Has class-action culture already hit Poland? In: ETEL M., KRAŚNICKA, I. \& PISZCZ, A. (eds). Court Culture - Conciliation Culture or Litigation Culture? Białystok: Temida2, 2014, pp. 137 - 147.

36 See: Informacja Prezesa UOKiK o działaniach służących wzmocnieniu ochrony konsumentów, jednocześnie wpisujących się w realizację „Polityki ochrony konkurencji i konsumentów” ["Information from the UOKiK President on measures to strengthen consumer protection, at the same time entering into the enforcement of the "Competition and consumer protection policy"], p. 9, in Polish available at: <http://orka2.sejm.gov.pl/INT8.nsf/klucz/283B8401/ \% 24FILE / z03345-ol.pdf>. Available at <https://www.uokik.gov.pl/news.php?news_id=12159>.

38 See decision of 30. 12. 2015, No. DDK-28/2015; in Polish available at: <https://decyzje.uokik.gov.pl/bp/dec_prez.nsf>. The decision is being proceeded by the Court of Competition and Consumer Protection to which it was appealed by the party. The service provider's misstep came at a price also in the other way, as the authority also fined the provider PLN 4,5 million (EUR 1,01 million).

39 See SIERADZKA, M. Rekompensata publiczna a inne środki usunięcia trwających skutków naruszenia zbiorowych interesów konsumentów [Public compensation against the background of other means of the elimination of lasting effects of the infringement of collective consumer interests]. In Internetowy Kwartalnik Antymonopolowy i Regulacyjny. Vol. 6(7) (2018), pp. $77-87$.

Ibid

41 On this criticism see in Polish <orka.sejm.gov.pl/SUE8.nsf/Pliki-zal/1124-18.rtf/\%24File/1124-18.rtf>.

42 COM/2018/0184 final - 2018/089 (COD). 
ahead to what approach to the UOKiK President's new decision-making practice will be taken by the courts of the first and second instance (and eventually the Supreme Court).

This last example proves that categories of the publicisation range from the statutory publicisation - either largo sensu (the first example) or stricto sensu (the second example) - to the de facto publicisation.

\section{$5 \quad$ CONCLUSION}

It follows from the above considerations that in practice the following categories of the publicisation can be observed in Poland:

1. de iure publicisation (statutory publicisation), that is the introduction of legal bases for public enforcement by legislature for matters that so far have been enforced privately or have been able to be enforced privately (legal bases for private enforcement have already existed) - as such it can be divided into:

a) publicisation largo sensu,

b) publicisation stricto sensu (de-privatisation), and

2. de facto publicisation.

On the one hand, the three above examples of the publicisation show that this phenomenon has been driven by efficiency reasons in all of them, and even though the effect is nevertheless small now, it can reasonably be expected that the publicisation will lead to a better law enforcement. The first and third examples are direct instances of the "helpful hand" addressed to weaker injured parties. In the third example the context of the administration of justice plays an important role. Additionally, in this case the de-privatization allows for being fair in procedures even vis-à-vis those (allegedly) unfair. Not only does this mean the de-privatization can offer the elimination of case backlogs, but it is also able to block the previously existing cost pathologies. Moreover, no real signs of fiscal functions of the publicisation have been seen so far (in particular in the first example where there have been no fining decisions yet and in the third example where the public compensation has been combined with lower fines or there have been no fines at all) but it must be remembered that more practice is needed to gain complete information in this regard and draw conclusions.

On the other hand, the publicisation continues to raise concerns. The second example may lead to the question of whether the right to a fair trial is or not unduly restricted in the case of the de-privatization understood as the elimination of legal bases for private enforcement and replacing them with legal bases for public enforcement in administrative proceedings which are initiated only $e x$ officio. The third example conveys the exciting potential of the innovative approach for including the public compensation in administrative decisions; however, it is accompanied by concerns around whether the resolution of civil claims can be deployed to private or public enforcement, wherever decision-makers consider it more seamless and cost-effective.

It may be that we will see even more successful examples of the publicisation of civil matters. There should be, however, not only a growing emphasis on regulatory impact assessments essential to the policy-making in particular from the perspective of cost-effectiveness, but also on the compatibility of new solutions with fundamental rights and principles. 


\section{Bibliography:}

BERNATT, M. Czy Polska oferuje więcej niż wymaga Konwencja? O konwencyjnym wymogu pełnej jurysdykcji i polskim modelu sądowej kontroli kar nakładanych przez Prezesa UOKiK [Does Poland offer more than the Convention requires? On the conventional requirement of full jurisdiction and the Polish model of judicial control of fines imposed by the UOKiK President]. In JASIŃSKI, W. (ed). Między prawem administracyjnym a prawem karnym. Standardy rzetelności postępowania w sprawach ochrony konkurencji i konsumentów [Between administrative law and criminal law. Standards of fairness of proceedings in cases of competition and consumer protection]. Warszawa: Wolters Kluwer, 2016.

HELIOS, J. Publicyzacja prawa prywatnego - prywatyzacja prawa publicznego w kontekście rozważań nad prawem europejskim [Publicisation of private law - privatisation of public law in the context of considerations on European law]. In Acta Universitatis Wratislaviensis Przegląd Prawa i Administracji. Vol. 92 (2013), pp. 11 - 36.

KORYCIŃSKA-RZĄDCA, P. Review of the New Polish Model of Abstract Control of Standard Forms of Agreements Concluded with Consumers. In Yearbook of Antitrust and Regulatory Studies. Vol. 9(14) (2016), pp. 247 - 264.

MiCHELON, C. The Public, the Private, and the Law. In MAC AMHLAiGH, C., MICHELON, C. \& WALKER, N. (eds). After Public Law. Oxford: Oxford Univeristy Press, 2013.

PISZCZ, A. Has class-action culture already hit Poland? In ETEL, M., KRAŚNICKA, I. \& PISZCZ, A. (eds). Court Culture - Conciliation Culture or Litigation Culture? Białystok: Temida2, 2014.

PISZCZ, A. The EU 2018 Draft Directive on UTPs in B2b Food Supply Chains and the Polish 2016 Act on Combating the Unfair Use of Superior Bargaining Power in the Trade in Agricultural and Food Products. In Yearbook of Antitrust and Regulatory Studies. Vol. 11(17) (2018), pp. 143 - 167.

SIERADZKA, M. Rekompensata publiczna a inne środki usunięcia trwających skutków naruszenia zbiorowych interesów konsumentów [Public compensation against the background of other means of the elimination of lasting effects of the infringement of collective consumer interests]. In Internetowy Kwartalnik Antymonopolowy i Regulacyjny. Vol. 6(7) (2018), pp. 77 - 87.

WATSON, A. The State, Law, and Religion. Pagan Rome. Athens and London: University of Georgia Press, 1992.

\section{Contact information:}

Dr. hab. Anna Piszcz

ORCID 0000-0001-7163-3292

piszcz@uwb.edu.pl

Department of Public Economic Law

Faculty of Law, University of Białystok

Adama Mickiewicza 1

15-213 Białystok

Poland 